\title{
Doomed to fail: the sad epistemological fate of ontological arguments
}

JOHN TURRI

john.turri@gmail.com

For beings like us, no ontological argument can possibly succeed. They are doomed to fail. The point of an ontological argument is to enable nonempirical knowledge of its conclusion, namely, that God exists. But no ontological argument could possibly enable us to know its conclusion nonempirically, and so must fail in that sense. An ontological argument will fail even if it is perfectly sound and begs no questions.

\section{Definition}

I begin by defining key terminology.

An ontological argument's nonempirical character distinguishes it from other theistic arguments. The principal goal of presenting or rehearsing an ontological argument is to promote the acquisition of inferential nonempirical knowledge that God exists, via acceptance of the conclusion based on competent deduction from the premises, which are themselves either nonempirically known or knowable. I will argue that, at least for beings like us, all ontological

\footnotetext{
This is a draft of a paper to appear in Ontological Proofs Today (Ontos Verlag), ed. Miroslaw Szatkowski. Comments welcome. Please don't cite, quote or refute without permission. This research was supported by the Social Sciences and Humanities Research Council of Canada.
} 
arguments must fail to achieve this goal.

By God I mean the god of classical western religious monotheism: the unique, eternal, omnipotent, omniscient, and omnibenevolent person who created and sustains the universe (Alston 1990: ch 1; Tooley 2009: section 1.1).

You inferentially know a proposition if and only if you know it based at least partly on inference from something else you accept. I use 'accept' broadly to include any kind of doxastic commitment, including belief, suspicion, faith, presupposition, etc. It is obvious that knowledge based on an argument is inferential.

You nonempirically know a proposition if and only if you know it in a way that is not even partly based on external perceptual experience. It is a harmless oversimplification to think of nonempirical knowledge in my sense as knowledge you could have, as they say, "from the armchair." You empirically know a proposition if and only if you know it based at least partly on external perceptual experience. It is possible to simultaneously know a proposition empirically and nonempirically, so long as you have sufficient independent bases for it.

An external perceptual experience is an experience produced by a power of the mind to receive signals from things other than itself (an "external channel"). ${ }^{1}$ Ordinary sensory experience counts as external perceptual experience. An external perceptual experience needn't have sensory content or any other sort of phenomenal or

1 I don't equate it with "exteroception" in the physiological sense, which pertains to detection of stimuli outside of the body. If the mind is identical to the body, then it would be equivalent to exteroception. 
conscious character. Actual cases of blindsight involve external perceptual experience, as would a phenomenal zombie's typical perceptual beliefs. ${ }^{2}$ Knowledge based on signals acquired through telepathy, clairvoyance and other forms of extra sensory perception, if such things exist, would count as empirical. By contrast, introspective awareness of one's mental conditions and concepts counts as nonempirical on my definition. Introspection is not an external channel. This fits nicely with the history of ontological argumentation. Anselm appeals to what exists "in the understanding" of even a fool, and in his argument Descartes notes, "clearly the idea of God . . . is one I discover to be . . within me." ${ }^{3}$ We could try to reconstruct these arguments without reference to introspection, but my approach doesn't force us to.

Innate knowledge counts as nonempirical on my definition. Perhaps it's possible that some innate knowledge is based on reasons, depending on what counts as basing an attitude on a reason. ${ }^{4}$ But I doubt that innate inferential knowledge is possible, because inferential knowledge requires completing an inference, and it's doubtful that you could come into existence having completed an inference. In any case, the point of an ontological argument - indeed of any argument - is obviously not the innate acquisition of knowledge; it's far too late for that by the time we're in a position to consider the argument. For this reason, in what follows I will expli-

2 Block (1995) dubs the processes "super-duper-blindperception." But "blind" pertains specifically to vision, so a better general label would be "super-duper-blankperception."

3 Meditation Five, trans. Donald Cress (Hackett: 1993).

4 Turri 2011 offers an account of basing. 
citly set aside innate knowledge.

Finally, it is perhaps worth noting that nonempirical knowledge in my sense is not the same thing as a priori knowledge in the standard sense. As it is often understood, a priori knowledge is knowledge based purely on rational intuition or understanding of concepts, perhaps along with inference from other things accepted similarly on the basis of rational intuition or understanding (BonJour 1998, Bealer 2000). Assuming a nonperceptual model of rational intuition, all a priori knowledge counts as nonempirical in my sense, but not all nonempirical knowledge in my sense counts as a priori. For example, introspective knowledge counts as nonempirical but not a priori.

\section{Doom}

Now I will present my main argument. The argument proceeds from three simple and intuitive premises. Remember that I am explicitly setting aside innate knowledge, so where I speak of knowing nonempirically, please understand me to mean knowing nonempirically and postnatally.

My first premise is that you cannot nonempirically know that another specific person exists now. You are the only specific person whom you can nonempirically know to exist now. You can know that other people exist now, of course, but you can know this only empirically. In order to know that others exist now, you must either (a) see them, hear them, touch them, smell them, or acquire some 
other sort of signal through an external channel, such as telepathy or clairvoyance, if such things are possible; or (b) remember things from previous external perceptual experiences, which somehow enables you to know that others presently exist. Such memories inherit their progenitors' empirical character.

I expect that this first premise is apt to seem uncontroversial, verging on the obvious. Even so, a vivid thought experiment can help us appreciate the point. Imagine that at some point in the near future, humanity plunges into a nuclear holocaust. Jade is buffeted by the blast, knocked unconscious in the otherwise empty and nondescript bomb shelter in her backyard. She suffers complete loss of declarative memory. Jade wakes up alone, numb and confused. It is completely dark, completely silent. She can see nothing, hear nothing, smell nothing, feel nothing, remember nothing. She wonders to herself, "Is there anyone else out there? Am I the only one?" It seems obvious that she can't know whether anyone else exists until she acquires some empirical evidence. She cannot, just by reflecting on her concepts and current mental condition, learn that she isn't alone, that other people currently exist.

Some philosophers have defended views about thought and language that might seem to threaten my first premise. Consider content externalism. Hilary Putnam asks, "Could we, if we were brains in a vat . . think that we were?" (1981: 31), and answers that we could not possibly do so. We couldn't think of vats unless we had a "causal connection to real vats" (1981: 37). And content externalism arguably generalizes to most or all of our concepts (Burge 1986). 
Moreover, content externalism is, like other philosophical theses, knowable nonempirically, if knowable at all. Grant that we do nonempirically know that content externalism is true. Thus you could nonempirically know that you have been causally connected to a community. You need only introspect that you have thoughts about a community, and reflect carefully enough to appreciate that this requires you to have had causal contact with a community. A community requires more than one person. So as long as you can nonempirically know that you are not more than one person, you can also nonempirically know that other people exist.

I'm willing to grant that you can know nonempirically that you are not more than one person, along with the other claims about what you can know nonempirically about your own thoughts and content externalism. But the objection under consideration still fails. Even supposing everything granted thus far, it doesn't follow that you can nonempirically know that other people now exist. At most it follows that you can nonempirically know that other people have at some point in time existed. Compare Jade's case. Let's grant that she can nonempirically know that she has been in causal contact with others, based on the introspectible fact that she asked herself whether others exist. She still can't knowledgeably infer that others exist now. And this has nothing special to do with the fact that her knowledge that others have existed is nonempirical. Adjust the case so that her amnesia isn't complete: she remembers, and thereby knows, that other people have existed. Thus her knowledge that others have existed is empirical. Yet she still can't knowledge- 
ably infer that anyone else exists now. That's still an open question for her.

A related objection to my first premise might derive from Davidson's triangulation theory of content. Davidson agrees with Putnam, Burge and others that content externalism is true. Moreover, Davidson agrees that content externalism has a dramatic antiskeptical upshot: we can know, just by reflecting on the nature of content and language, that systematic perceptual error is ruled out. "Anyone who accepts [content] externalism knows that he cannot be systematically deceived about whether there are such things as cows, people, water, stars, and chewing gum" (Davidson 1990: 201). Of course, this isn't enough to help in Jade's case because she doesn't believe that others presently exist; she suspends judgment on that question. Moreover, due to her amnesia she lacks knowledge and beliefs about others. So she can't infer that most of her beliefs about others are true.

But there is more to Davidson's theory. Having granted that our beliefs are about what typically causes them, Davidson asks, "what has typically caused them?" Consider our beliefs about cows. Why think that cows cause these beliefs rather than, say, "events spatially closer to the thinker than any cow?" Davidson claims that there is a "social basis" for determining the answer. The relevant cause is picked out by how other people interpret the thinker. Thought requires an "essential triangle" of thinker, environment and interpreter: "The presence of two or more creatures interacting with each other and with a common environment" is required for 
thinking to occur (Davidson 1990: 202-3). Triangulation determines the relevant causal relations and, thus, the content of all thought.

Even if we grant everything Davidson says about triangulation, it doesn't threaten my first premise. Suppose that you can nonempirically know that you're having thoughts. And suppose that you can nonempirically know that your thoughts are typically about what causes them, and that this requires you to have interacted with another person in a common environment. You still can't knowledgeably infer that another person exists now. Nothing in Davidson's view requires that another person monitor you whenever you have a thought, or usually when you have a thought, or even recently when you've had a thought. (Not even Big Brother's Thought Police could ensure that everyone was monitored whenever they had a thought.) Thus you can't knowledgeably infer that others are now monitoring you, and so exist now. That's still an open question for you.

My second premise is that if any ontological argument can succeed for you, then you can nonempirically know that God, a person, exists now. For if it were to succeed, then you would nonempirically know that God exists. And it's trivially obvious that if God exists, then God exists eternally, including now; this is a simple conceptual truth, which you can and do know nonempirically. And it's trivially obvious that God is a person; this is a simple conceptual truth, which you also can and do know nonempirically.

My third premise is that you are not God. Disappointing as that 
9 | John Turri

may be, I trust that you will, at least upon cool reflection, agree that this premise needs no defense.

From those three premises it follows that no ontological argument can succeed for you. For if any ontological argument can succeed for you, then you can nonempirically know that God, a person, exists now. But you are the only person whom you can nonempirically know to exist now. So either you are God, or no ontological argument can succeed for you. But you are not God. So no ontological argument can succeed for you.

Moreover, there's nothing special about you in this regard. The same is true for all humans. So no ontological argument can succeed for any of us. For us, ontological arguments are doomed to fail. In fact, if my argument is correct, then presumably God is the only person for whom an ontological argument could succeed. I accept this consequence of the argument.

If a more formal representation of the basic argument is desired, the following will suffice. (Note that the numbered premises in this formal rendition don't correspond to the ordinally numbered premises of the informal presentation above.)

\section{(Doomed)}

1. If you can nonempirically know that a certain person exists now, then you $=$ that person. (Premise)

2. If God exists, then God is a person. (Premise)

3. So if you can nonempirically know that God exists now, then you $=$ God. $($ From 1-2)

4. If any ontological argument can succeed for you, then you 
can nonempirically know that God exists now. (Premise)

5. So if any ontological argument can succeed for you, then you $=$ God. $($ From 3-4)

6. You $\neq$ God. (Premise)

7. So no ontological argument can succeed for you. (From 5-6)

8. If no ontological argument can succeed for you, then no ontological argument can succeed for any of us. (Premise)

9. So no ontological argument can succeed for any of us. (From $7-8)$

\section{Delimitation}

This section emphasizes some limitations and unique features of my argument.

First, I have neither argued for nor committed myself to any of the following claims:

- God couldn't possibly exist.

- God doesn't exist.

- You can't know that God exists.

- You can't innately know that God exists.

- You can’t empirically know that God exists.

- You can't know by testimony that God exists.

- You can't know by revelation that God exists.

- You can't nonempirically know that any god whatsoever exists.

Regarding the last item, nothing in my argument speaks against 
nonempirical knowledge of impersonal gods. For example, perhaps we can know nonempirically that an infinite impersonal substance exists, and perhaps that counts as divine. That is consistent with everything I say here.

Second, I have neither utilized nor committed myself to any of the following general grounds for rejecting ontological arguments:

- Ontological arguments are invalid.

- Ontological arguments have a false premise.

- Ontological arguments are unsound.

- Ontological arguments suffer refutation by parody.

- Ontological arguments beg the question.

- Question-begging arguments must fail.

- Persuasiveness to opponents is a criterion of a successful argument.

- Persuasiveness to reasonable and neutral third parties is a criterion of a successful argument.

- Nonempirical knowledge would have to be infallible, indefeasible, or certain.

Finally, I have neither assumed nor committed myself to any of the following specific claims which feature centrally in some traditionally influential responses to the ontological argument:

- Existence is not a predicate.

- Existence is not a first-order predicate.

- Existence is not a perfection.

- The concept of God is inconsistent. 


\section{Conclusion}

In closing, I would like to consider one final objection. Suppose that a proponent of the ontological argument rejects my premise that you are the only person whom you can nonempirically know to exist now. And suppose that this proponent offers the ontological argument itself as a counterexample to my premise. In that case, I am content to let the entire matter rest on the comparative plausibility of the two competing claims: on the one hand, that knowledge of other people's current existence requires empirical support, and on the other, that the ontological argument succeeds. I know which one seems more probable to me. Others will of course decide the matter for themselves.

Word count: 2603 


\section{References}

Anselm. 1077. Proslogion.

Alston, William P. 1990. Perceiving god: the epistemology of religious experience. Cornell UP.

Bealer, George. 2000. A theory of the a priori. Pacific philosophical quarterly 81: 1-30.

Block, Ned. 1995. On a confusion about consciousness. Behavioral and brain sciences 18: 227-247.

Burge, Tyler. 1986. Individualism and psychology. Philosophical review 95: 3-45.

Davidson, Donald. 1990. Epistemology externalized. Reprinted in Subjective, intersubjective, objective. Oxford UP, 2001: 193204.

Descartes, Rene. 1641. Meditations on first philosophy.

Hume, David. 1779. Dialogues concerning natural religion. http://www.gutenberg.org/ebooks/4583. Accessed February 2012.

Putnam, Hilary. 1981. Brains in a vat. Reason, truth and history. Cambridge UP. Reprinted in Skepticism: a contemporary reader. Ed. Keith DeRose and Ted Warfield. Oxford UP, 1999: 27-42.

Tooley, Michael. 2010. The problem of evil. Stanford encyclopedia of philosophy. Spring 2010 edition. Ed. Edward N. Zalta. URL: < http://plato.stanford.edu/archives/spr2010/entries/evil/>. Accessed February 2012.

Turri, John. 2011. Believing for a reason. Erkenntnis 74: 383-397. 